\title{
Tsunamigenic potential of a Holocene submarine landslide along the North Anatolian Fault (northern Aegean Sea, off Thasos island): insights from numerical modelling
}

\author{
Alexandre Janin ${ }^{1}$, Mathieu Rodriguez ${ }^{1}$, Dimitris Sakellariou ${ }^{2}$, Vasilis Lykousis ${ }^{2}$, and Christian Gorini ${ }^{3}$ \\ ${ }^{1}$ Laboratoire de Géologie de l'Ecole normale supérieure de Paris, PSL Research University, CNRS UMR 8538, \\ 24 rue Lhomond, 75005 Paris, France \\ ${ }^{2}$ Institute of Oceanography, Hellenic Center of Marine Research, 19013 Anavyssos, Greece \\ ${ }^{3}$ Sorbonne Universités, UPMC Université Paris 06, UMR 7193, ISTeP, 75005, Paris, France
}

Correspondence: Alexandre Janin (alexandre.janin@ens.fr)

Received: 13 November 2017 - Discussion started: 7 February 2018

Revised: 11 December 2018 - Accepted: 25 December 2018 - Published: 16 January 2019

\begin{abstract}
The North Anatolian Fault in the northern Aegean Sea triggers frequent earthquakes of magnitudes up to $M_{\mathrm{w}} \sim$ 7. This seismicity can be a source of modest tsunamis for the surrounding coastlines with less than $50 \mathrm{~cm}$ height according to numerical modelling and analysis of tsunami deposits. However, other tsunami sources may be involved, like submarine landslides. We assess the severity of this potential hazard by performing numerical simulations of tsunami generation and propagation from a Holocene landslide $\left(1.85 \mathrm{~km}^{3}\right.$ in volume) identified off Thasos. We use a model coupling the simulation of the submarine landslide, assimilated to a granular flow, to the propagation of the tsunami wave. The results of these simulations show that a tsunami wave of water height between 1.10 and $1.65 \mathrm{~m}$ reaches the coastline at Alexandroupoli (58000 inhabitants) $1 \mathrm{~h}$ after the triggering of the landslide. In the same way, tsunami waves of water height between 0.80 and $2.00 \mathrm{~m}$ reach the coastline of the Athos peninsula $9 \mathrm{~min}$ after the triggering of the landslide. Despite numerous earthquakes of $M_{\mathrm{w}}>7$ and strong detrital input (on the order of $30 \mathrm{~cm} \mathrm{ka}^{-1}$ ), only a few Holocene landslides have been recognized so far, asking for tsunami recurrence in this area.
\end{abstract}

\section{Introduction}

Tsunamis constitute a major natural hazard for coastal populations and infrastructure. Tsunamis result from an impulsive perturbation of the seafloor, which generates waves with a wavelength $\lambda \sim 100 \mathrm{~km}$ and a period in the 10-30 min range. According to the shallow-water approximation, the phase velocity of tsunami waves is expressed by $c=\sqrt{g h}$ at long periods, where $h$ is the bathymetry and $g$ is the gravitational acceleration. Although most of the deadliest tsunamis in the last decades result from earthquakes nucleated along submarine faults (Okal, 2015), other sources of damaging tsunamis have been identified, including submarine landslides (Tappin et al., 2008; ten Brink et al., 2014). One of the most conspicuous case study is the July 1998 event that struck the coastline of Papua New Guinea. There, a $M_{\mathrm{w}} \sim 7$ earthquake triggered a $\sim 4 \mathrm{~km}^{3}$ submarine landslide off the Sissano Lagoon. The slide motion generated a tsunami with run-up values that were locally $>10 \mathrm{~m}$, which caused more than 2200 casualties (Heinrich et al., 2000; Heinrich et al., 2001; Tappin et al., 2001, 2008). In the wake of the 1998 Sissano event, numerous studies investigated the distribution of submarine landslides along continental slopes, islands and bathymetric highs, as well as the tsunamigenic potential (Canals et al., 2004; Masson et al., 2006; McAdoo et al., 2000; Chaytor et al., 2009; Twichell et al., 2009; Mulder et al., 2009; Tappin, 2010; Iacono et al., 2014; Urgeles and Camerlenghi, 2013; Macías et al., 2015; Palomino et al., 2016; Rodriguez et al., 2012; Rodriguez et al., 2013, 2017; Katz et al., 2015). Sub- 
marine landslide-generated tsunamis display specific characteristics compared to other sources (Trifunac and Todorovska, 2002; Harbitz et al., 2006, 2014). Vertical displacements induced by the slide can be larger than displacements caused by earthquake-related on-fault seafloor rapture and thus may produce higher wave amplitudes (Okal and Synolakis, 2003). Landslide motion can last over several minutes to hours, leading to complex patterns of wave interactions that either amplify or attenuate the wave amplitude (Haugen et al., 2005; Harbitz et al., 2006; Ma et al., 2013; Løvholt et al., 2015). For landslide volumes on the order of a few $\mathrm{km}^{3}$, frequency dispersion of the tsunami results in shorter wavelengths and faster wave amplitude attenuation, and limits the far-field propagation of the tsunami.

Tsunami hazards along submarine strike-slip faults remain poorly investigated. Indeed, earthquakes along strikeslip faults generate only minor vertical displacements of the seafloor, and hence a minor tsunami with an amplitude on the order of a few centimetres. However, releasing or restraining bends with steep slopes may take place along strikeslip faults, promoting submarine failures. For instance, the $M_{\mathrm{w}}=6.9$ Loma Prieta earthquake along the San Andreas Fault excited tsunamis up to $40 \mathrm{~cm}$ high in Monterey Bay, which required a landslide as a secondary source (Ma et al., 1991). The lack of investigation into submarine landslides along a submarine strike-slip fault may therefore result in underestimation of tsunami hazards in some places.

The North Anatolian Fault (Fig. 1) is a major $\sim 1200 \mathrm{~km}$ long continental strike-slip boundary, which takes up the dextral relative motion between Anatolia and Eurasia at a current rate of $\sim 25 \mathrm{~mm} \mathrm{yr}^{-1}$ (Reilinger et al., 2006, 2010; Perouse et al., 2012; Müller et al., 2013). In the northern Aegean domain, the rate decreases from $21.2 \mathrm{~mm} \mathrm{yr}^{-1}$ at the Gulf of Saros to $7 \mathrm{~mm} \mathrm{yr}^{-1}$ at the Sporades archipelago (Müller et al., 2013). The North Anatolian Fault is one of the most active fault systems in Europe with several earthquakes above $M_{\mathrm{w}} \sim 7$ recorded from instrumental seismology in the last decades, including the deadly Izmit and Duzce events in 1999 (Hubert-Ferrari et al., 2000; Bulut et al., 2018). Detailed historical (Altinok et al., 2011) and field studies (Meghraoui et al., 2012) additionally revealed the geological signature of numerous past Holocene earthquakes and tsunamis. In the Marmara Sea, the response of sedimentary systems to the seismic activity has been investigated throughout detailed stratigraphic comparisons between the timing of mass-wasting events and the timing of earthquakes (McHugh et al., 2006; Beck et al., 2007; Drab et al., 2012, 2015). Multibeam and seismic reflection data revealed the signature of numerous submarine landslides (Grall et al., 2012, 2013), some of which may have triggered tsunamis including the AD 1509 event (Hébert et al., 2005; Özeren et al., 2010; Alpar et al., 2001; Yalçıner et al., 2002).

Although numerous tsunami deposits have been identified in the geological record along the northern Aegean coastlines (Reicherter et al., 2010; Papadopoulos et al., 2014; Mathes-
Schmidt et al., 2009) and despite the numerous cities along the coastline, the tsunamigenic potential of submarine landslides in this area remains only preliminarily investigated (Karambas and Hasiotis, 2012). The North Aegean Trough is a strike-slip basin emplaced along the North Anatolian Fault. Its tectono-sedimentary context is very similar to the Marmara Sea with splays of the North Anatolian Fault, triggering frequent earthquakes up to $M_{\mathrm{w}} \sim 7$ (such as the 24 May 2014 $M_{\mathrm{w}}=6.9$ event in the Gulf of Saros) and with locally gascharged sediments (Papatheodorou et al., 1993). However, only one conspicuous submarine landslide has been identified so far along the edges of the North Aegean Trough (Lykousis et al., 2002). This submarine landslide was emplaced at $40^{\circ} 15^{\prime} \mathrm{N}, 24^{\circ} 52^{\prime} \mathrm{E}$, off Thasos island, somewhere between 5500 and 7500-8500 years ago, and removed several $\mathrm{km}^{3}$ of sediments (Lykousis et al., 2002). The slide was triggered at $300 \mathrm{~m}$ depth, less than $50 \mathrm{~km}$ away from the surrounding coastlines, i.e. a configuration very similar to the 1998 Sissano event in Papua New Guinea. For simplicity, this landslide is hereafter referred to as the Thasos landslide. The objective of this paper is to investigate whether the Thasos landslide could have been a potential source of tsunami along the Aegean coasts by means of numerical modelling of tsunami generation and propagation. A particular emphasis is put on the possible wave interactions related to the complex morphology of the Aegean coastlines, with numerous islands, bays and peninsulas (Fig. 1). We adopt a deterministic approach based on the evaluation of credible scenarios defined and validated on the basis of the similarity between the observed and the modelled landslide extents.

\section{Geological background of the northern Aegean Sea and description of the Thasos submarine landslide}

\subsection{Tectonics and morphology}

The geological history of the Aegean Sea takes place in the complex realm of the collision between Africa and Eurasia during the Cenozoic. The Aegean domain used to be a mountain belt (Hellenides) during the early Cenozoic, which collapsed since the late Eocene-early Oligocene, in close relationship with the southwards retreat of the Hellenic trench (Jolivet and Faccenna, 2000; Jolivet and Brun, 2010; Jolivet et al., 2013, 2015; Brun et al., 2016). Since the late Miocene, strike-slip tectonics along the North Anatolian Fault system accommodate the lateral escape of Anatolia (Armijo et al., 1999; Faccenna et al., 2006; Hubert-Ferrari et al., 2009; Le Pichon et al., 2015; Bulut et al., 2018; Sakellariou and Tsampouraki-Kraounaki, 2018; Ferentinos et al., 2018). In the northern Aegean Sea, the North Anatolian Fault system is divided into two main strike-slip systems, shaping the morphology of the seafloor. The age of inception of these strikeslip segments is estimated in the Plio-Pleistocene from ties 


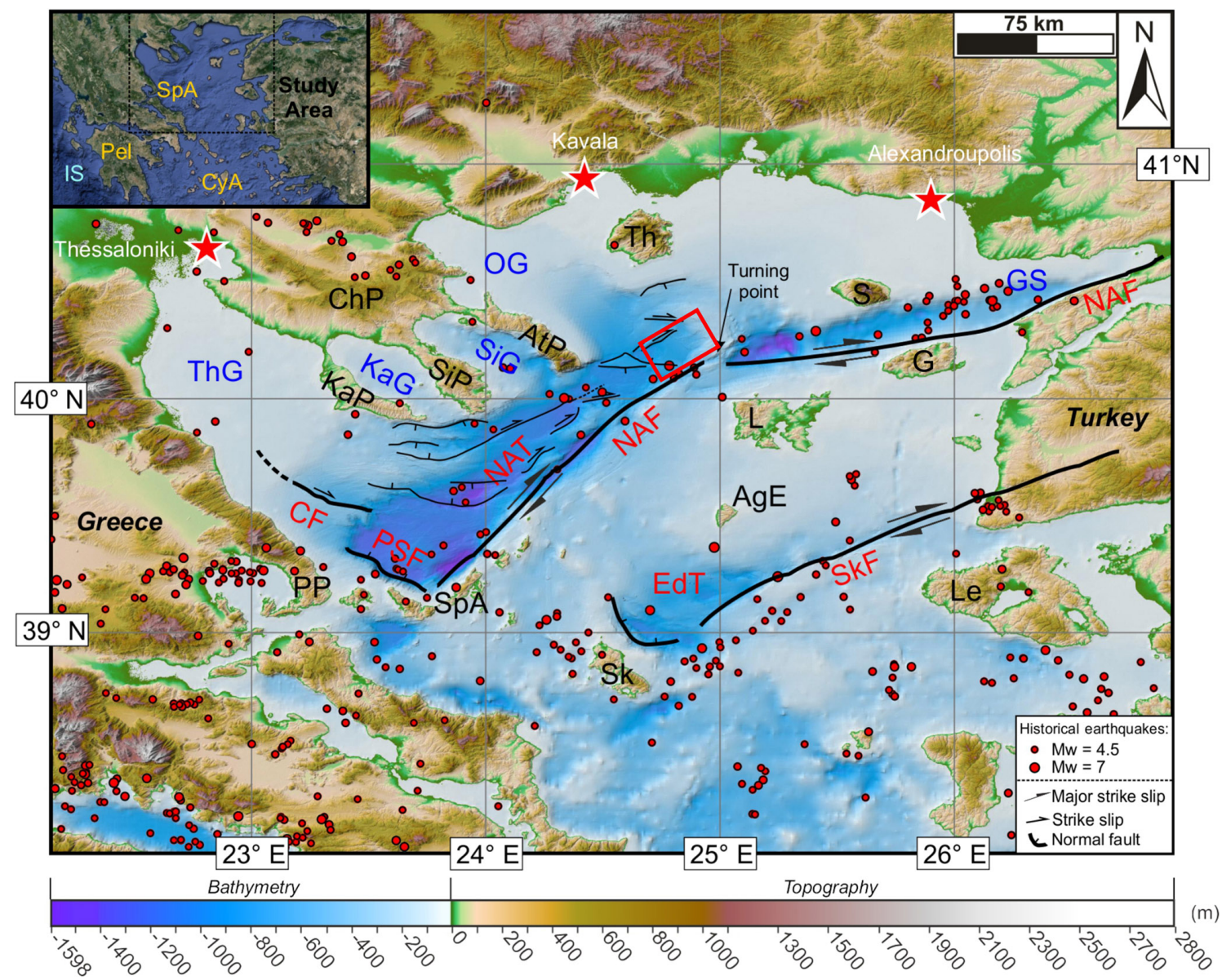

Figure 1. General morphological features of the studied area. The main faults are indicated (after Sakellariou and Tsampouraki-Kraounaki, 2016). Seismicity since 1 January 1950 is taken from USGS for earthquakes with $M_{\mathrm{W}}>4.5$. The red rectangle gives the location of the Thasos landslide. In the inset is the location of the study area (background from Google Earth). AgE is Agios Efstratios, AS is Aegean Sea, AtP is Athos peninsula, ChP is Chalkidiki peninsula, CyA is Cyclades archipelago, EdT is Edremit Trough, G is Gokceada (Imbros), GS is Gulf of Saros, IS is Ionian Sea, KaG is Kassandra Gulf, KaP is Kassandra peninsula, L is Lemnos, Le is Lesbos, NAT is North Aegean Trough, NAF is North Anatolian Fault, OG is Gulf of Orfani, Pel is Peloponnese, PP is Pelion peninsula, PSF is Pelion-Skopelos Fault, S is Samothrace, $\mathrm{SiG}$ is Sigitikos Gulf, SiP is Sithonia peninsula, Sk is Skyros, SkF is Skyros Fault, SpA is Sporades archipelago and Th is Thasos, ThG is Thermaic Gulf. General topography and bathymetry from SRTM30 (Becker et al., 2009) and high-resolution bathymetry $(250 \mathrm{~m})$ are from Sakellariou and Tsampouraki-Kraounaki (2016).

of a vintage seismic data set with industrial wells (Beniest et al., 2016).

The first, main fault segment to the north runs along the Gulf of Saros, where it forms an en echelon, a negative flower structure system that connects the North Aegean Trough (Fig. 1) (Kurt et al., 2000; McNeill et al., 2004). This segment accommodates dextral shearing at a $\sim 20 \mathrm{~mm} \mathrm{yr}^{-1}$ rate (Le Pichon and Kreemer, 2010; Perouse et al., 2012). It corresponds to the prolongation of the Main Marmara Fault (Roussos and Lyssimachou, 1991; Le Pichon et al., 2001), west of the Dardanelles Strait (Fig. 1). Numerous oblique NW-SE to E-W splays connect the North Anatolian Fault and form a horsetail structure, typical of strike-slip fault terminations. The horsetail structure forms a $\sim 150 \mathrm{~km}$ long, $\sim 60 \mathrm{~km}$ wide, $\sim 1500 \mathrm{~m}$ deep basin, referred to as the
North Aegean Trough (Papanikolaou et al., 2002; Sakellariou and Tsampouraki-Kraounaki, 2016; Sakellariou et al., 2016), where the oblique splays isolate a series of half-grabens, tilted over a crustal detachment at $\sim 10 \mathrm{~km}$ depth (Laigle et al., 2000). This complex structural pattern results in a very uneven bathymetry, with a series of bathymetric highs and lows within the North Aegean Trough. Southwards, the second strike-slip splay corresponds to the southern branch of the North Anatolian Fault, active at a $\sim 5 \mathrm{~mm} \mathrm{yr}^{-1}$ rate (Le Pichon and Kreemer, 2010; Le Pichon et al., 2014). This structure ends off Skyros island, where it forms the Edremit Trough (Fig. 1). 


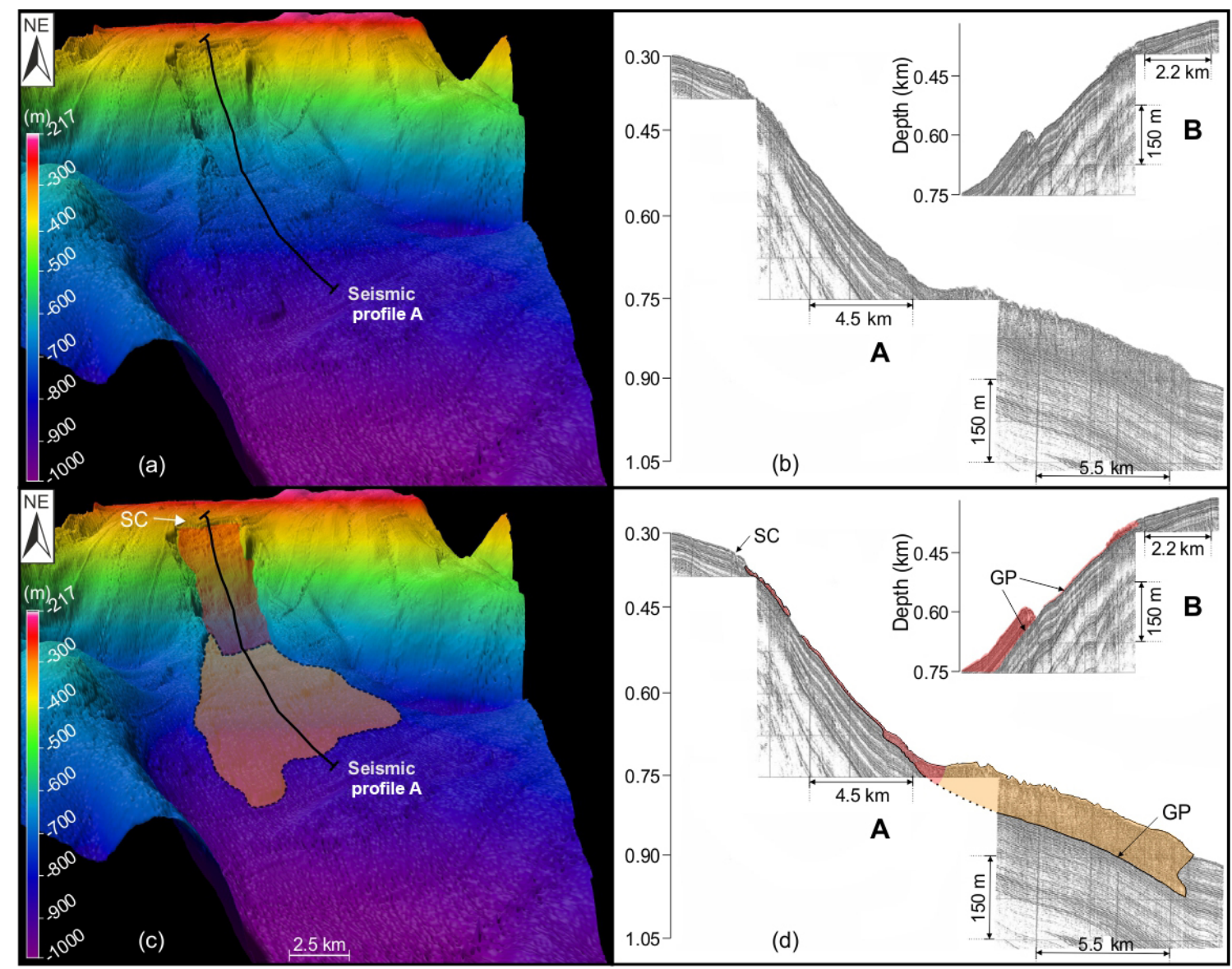

Figure 2. Features of the Thasos submarine landslide. In red is the first unit, in orange is the second unit. (a) 3-D view of the actual bathymetry of the Thasos landslide. (b) Raw seismic profiles from Lykousis et al. (2002): (A) downslope air-gun sub-bottom profile indicated on (a) and (B) details of the seismic profile along the major glide zone. (c) Interpretation of the 3-D bathymetry: in red is the area in which the deposit is thin or non-existent in the upper part of the slide; in orange is the area where the deposit is thick (marked on the bathymetry by a hummocky facies and in the seismic profile by chaotic and hyperbolic reflectors); SC is slide scarp. (d) Interpretation of seismic profiles with the same convention as in (c), GP is the glide plane. Panels (b) and (d) are modified after Lykousis et al. (2002).

\subsection{Sedimentology}

During the Quaternary, the deposition of detritic sediments coming from the surrounding lands (Suc et al., 2015) has been controlled by fast subsidence ( 0.3 to $1.5 \mathrm{~m} \mathrm{Kyrs}^{-1}$ ) (Piper and Perissoratis, 1991) and glacio-eustatic variations in sea level (İşler et al., 2008). In the vicinity of the North Aegean Trough, the late Quaternary (i.e. last $150 \mathrm{kyrs}$ ) sediments are composed of pro-delta formations, composed of sandy to silty turbidites (Piper and Perissoratis, 1991; Lykousis et al., 2002). The uppermost sediments ( $2 \mathrm{~m}$ below the seafloor) consist of normally consolidated or slightly overconsolidated muddy to silty sediments, with a bulk density of sediments ranging between 1.4 and $1.5 \mathrm{~g} \mathrm{~cm}^{-3}$ (Lykousis et al., 2002).

\subsection{The Holocene Thasos submarine landslide}

On the bathymetry, the slide of around a $30 \mathrm{~km}$ long scar encloses an area of $85 \mathrm{~km}^{2}$. Downslope, a $75 \mathrm{~m}$ thick lobeshaped deposit spans an area of $\sim 50 \mathrm{~km}^{2}$ (Fig. 2a, b) (Lykousis et al., 2002). The mass-transport deposit is characterized by a hummocky facies on the seafloor and displays a typical facies composed of chaotic and hyperbolic reflectors on the seismic profiles (Unit 2, in orange on Fig. 2b, c). A second $5 \mathrm{~m}$ thick minor mass-transport deposit spreads across the failure plan over $8.7 \mathrm{~km}$ from the top the scarp (Unit 1, in red on Fig. 2b, c). The initial volume, mobilized during the first step of the failure, is estimated following the method described in Ten Brink et al. (2006). It consists in filling in the failed area according to the adjacent scar height. The difference between the filled-in grid and the grid displaying the slide scar gives an initial failed volume at $1.85 \mathrm{~km}^{3}$ in the case of the Thasos slide. The volume of the lobe-shaped 
Table 1. Table of key parameters used for produced the two most credible scenarios. Vi is initial volume, TRUN is total simulated time, the slide stops its displacement at TSLISTOP seconds after being triggered, PHIBAS is basal friction angle, $e_{\mathrm{W}}$ is water entrainment coefficient and $\mathrm{Vf}$ is final volume of the slide.

\begin{tabular}{lcccccc}
\hline Credible scenarios & $\mathrm{Vi}\left(\mathrm{km}^{3}\right)$ & TRUN(s) & TSLPISTOP(s) & PHIBAS $\left(^{\circ}\right)$ & $e_{\mathrm{w}}$ & $\mathrm{Vf}\left(\mathrm{km}^{3}\right)$ \\
\hline First scenario & 1.8511 & 7200 & 600 & 1.0 & $1 \times 10^{-3}$ & 3.6938 \\
Second scenario & 1.8511 & 7200 & 1700 & 1.5 & $5 \times 10^{-4}$ & 4.1103 \\
\hline
\end{tabular}

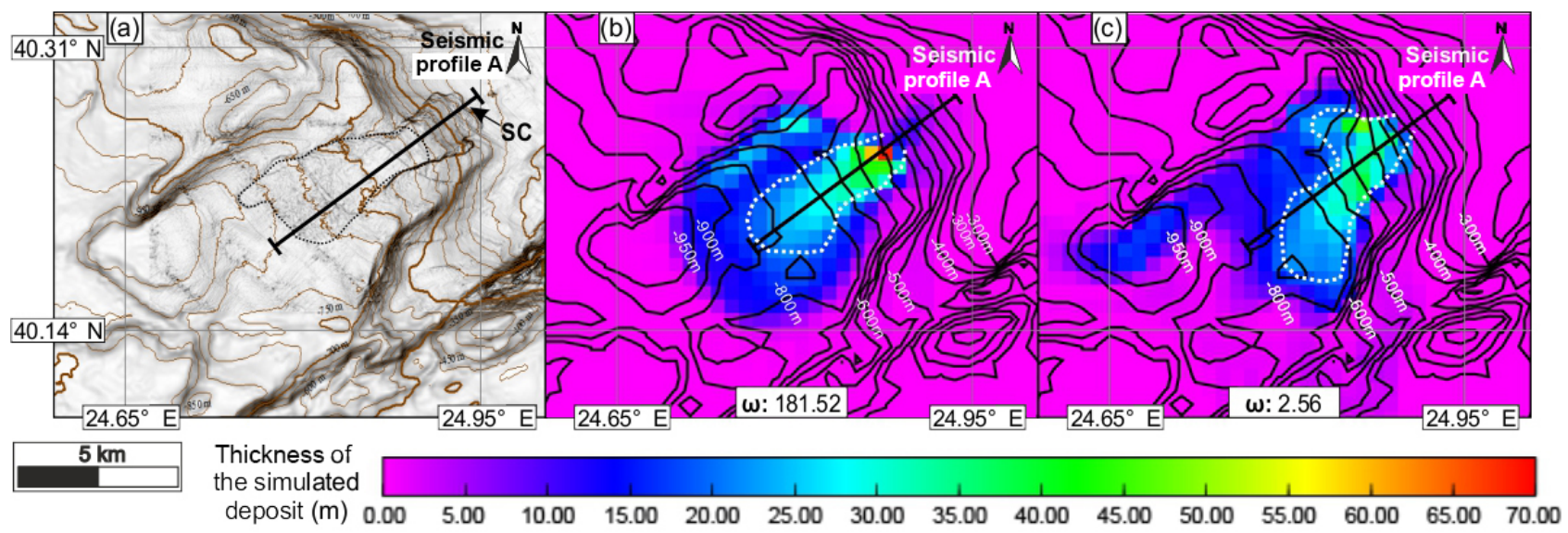

Figure 3. Numerical reconstruction of the final position of the slide for the two credible scenarios. (a) Multibeam bathymetry of the slide. Black dotted line corresponds to the limit of the slide deposit (in orange on Fig. 2). (b) The position of the slide's deposit for the first credible scenario. White dotted line highlights the main transport deposit (above $20 \mathrm{~m}$ thick). The resolution of the seismic profile is not enough to track a mass-transport deposit thinner than $20 \mathrm{~m}$. (c) The position of the slide's deposit for the second credible scenario with the same convention as in (b). $\omega$ is a coherence index. The higher this index is, the closer the simulation is to the observable data. This index is defined with normalized inverse-distance weighting (Appendix A). SC is slide scarp.

mass-transport deposit lying at the bottom of the scar is estimated at $\sim 3.8 \mathrm{~km}^{3}$ (Lykousis et al., 2002). The difference between the initial failed volume and the final volume of the slide means that during its flow, the slide has captured sediments from the adjacent slope. The slide evolved as a translational slide of well-bedded sediments, over a glide plane corresponding to a muddy weak layer deposited 170245 kyrs ago (Lykousis et al., 2002). Although earthquake shaking related to the activity of the North Anatolian Fault may be considered the most likely trigger of submarine landslides, recent $M_{\mathrm{w}} \sim 7$ events did not trigger significant landslides and tsunami, despite the unstable state of the North Aegean Trough slopes (Lykousis et al., 2002). This discrepancy between strong earthquakes and landslide frequencies has been highlighted in various tectono-sedimentary contexts (Völker et al., 2011; Strozyk et al., 2010; Pope et al., 2015, 2016). Various processes may explain this discrepancy, including the amount and the nature of sedimentary supply, local variations in physical properties of the sediments (Lafuerza et al., 2012) or the overcompaction of the sediments subsequent to the fluid release induced by the seismic wave shaking (Hampton et al., 1996; Strozyk et al., 2010). Some mass-transport deposits, probably older than Holocene, can be guessed on sparker lines in the Sporades basin (Brooks and Ferentinos, 1980; Ferentinos et al., 1981; Sakellariou et al., 2018; Rodriguez et al., 2018) and on sub-bottom profiles crossing the Gulf of Saros (McNeill et al., 2004). However, a comprehensive map of the spatial distribution of landslides and precise stratigraphic constraints on their recurrence are lacking for a further description of how the sedimentary system reacts to the seismic activity of the North Anatolian Fault.

\section{Numerical modelling of the submarine landslide and the associated tsunami}

\subsection{Bathymetric data set}

The bathymetric grid used for tsunami calculations is a compilation of several grids of different resolutions. We use the multibeam grid previously published in Papanikolaou et al. (2002), acquired with a seabeam 2120 working at $20 \mathrm{kHz}$. The horizontal resolution is $\sim 100 \mathrm{~m}$ for a vertical resolution on the order of $1 \mathrm{~m}$. At the slide location, we include the high-resolution ( $30 \mathrm{~m}$ horizontal resolution) grid acquired by HCMR in 2013-2015 on board the Aegeo, in the frame of the YPOTHER project (Sakellariou et al., 2016). The remaining 
Table 2. Table of maximum elevation $(\mathrm{cm})$ of the water level for 10 places where the tsunami was amplified. Top means above the marine landslide, AgE is Agios Efstratios, AtP is Athos peninsula, L is Lemnos (Gulf of Pournia), OG is Gulf of Orfani, SpA is Sporades archipelago and $\mathrm{Th}$ is Thasos.

\begin{tabular}{lrrrrrrrrrr}
\hline Credible scenarios & Top & Th & L & AgE & SpA & AtP & OG & Kavala & Alexandroupoli & Turkey \\
\hline First scenario & 360 & 115 & 140 & 145 & 145 & 145 & 120 & 65 & 165 & 75 \\
Second scenario & 470 & 75 & 105 & 110 & 80 & 120 & 40 & 25 & 60 & 40 \\
\hline
\end{tabular}

gaps have been filled in with the SRTM PLUS bathymetry (Becker et al., 2009).

\subsection{Slide modelling: physical background and limits}

We use the AVALANCHE code that has been successfully tested from comparisons with tidal measurements for the 1998 Papua New Guinea tsunami (Heinrich et al., 2000) and the 1979 Nice event (Labbé et al., 2012). Two approaches are commonly used to model the dynamics of a submarine landslide. A first approach assimilates the slide to a viscous flow, with a Bingham rheology. The slide is divided into a bottom layer submitted to shear along the glide plane and a top plug layer with a uniform velocity profile (Jiang and LeBlond, 1993). This approach efficiently reproduced some landslides in the Mediterranean Sea (Iglesias et al., 2012; Løvholt et al., 2015). However, in our case, all the simulations carried out for a reasonable range of dynamic viscosities $\left(25-500 \mathrm{~m}^{2} \mathrm{~s}^{-1}\right)$ failed to reproduce the first-order morphology of the Thasos slide and led to excessive run-out and volume values. The second approach, which assimilates the propagation of the landslide to a granular flow (Savage and Hutter, 1989), produced more convincing results in our case, which may be consistent with the detritic nature of the sediments off Thasos (Piper and Perissoratis, 1991; Lykousis et al., 2002). Modelling the slide as a granular flow implies the sediment loses its cohesion immediately after failure occurred at the glide plane. This model assumes that the energy dissipated at the glide plane is much higher than the energy dissipated within the sedimentary flow itself. Although large deformations throughout the thickness of the flow are inevitable (ten Brink et al., 2014) and may have important effects on the evolution of the tsunami wave (Ma et al., 2013), the configuration of the slide (thickness smaller than its length and its width) allows the use of the shallow-water assumption (Savage and Hutter, 1989) and therefore the simplification of the mechanical behaviour within the sedimentary flow. Deformations within the flow in the earliest stages of collapse are also neglected, as well as the added mass effect (Løvholt et al., 2015), which may result in slightly overestimated initial acceleration (on the order of $10^{-2} \mathrm{~m} \mathrm{~s}^{-2}$ ). The velocity of the flow in the direction parallel to the slope is considered constant over the entire thickness of the slide. Basal friction at the glide plane is modelled by a Coulombtype friction law (Savage and Hutter, 1989). This law assumes a constant ratio of the shear stress to the normal stress at the base of the slide and involves a dynamic friction angle $\phi$ between the rough bed and the sliding mass. Granular flows commonly occur for internal friction angles $(\phi)$ around $30-40^{\circ}$. However, this range of values is not appropriate for submarine landslides, which involve $\phi$ values $<15^{\circ}$ (Canals et al., 2004; Ten Brink et al., 2009) and even $\phi$ values $<2^{\circ}$ for low slope gradient (Rodriguez et al., 2012; Urlaub et al., 2015). Therefore, we perform simulations only for friction angles ranging between 1 and $5^{\circ}$ to simulate the Thasos landslide, which spans the range of slope values in this area. The non-linear and non-dispersive equations from shallow-water assumption, written in a coordinate system linked to the topography, give us (Heinrich et al., 2000) fluid mass conservation,

$\frac{\partial h}{\partial t}+\frac{\partial}{\partial x}(h u)+\frac{\partial}{\partial y}(h v)=e_{\mathrm{w}}(u+v) ;$

momentum conservation equations,

$$
\begin{aligned}
& \frac{\partial}{\partial t}(h u)+\alpha \frac{\partial}{\partial x}(h u \cdot u)+\alpha \frac{\partial}{\partial y}(h u \cdot v)=-\frac{1}{2} \kappa \frac{\partial}{\partial x}\left(g h^{2} \cos \theta\right) \\
& \quad+\kappa g h \sin \theta_{x}-\tau_{x z(z=0)} \\
& \frac{\partial}{\partial t}(h v)+\alpha \frac{\partial}{\partial x}(h v \cdot u)+\alpha \frac{\partial}{\partial y}(h v \cdot v)=-\frac{1}{2} \kappa \frac{\partial}{\partial y}\left(g h^{2} \cos \theta\right) \\
& \quad+\kappa g h \sin \theta_{y}-\tau_{y z(z=0)} ;
\end{aligned}
$$

sediment mass conservation,

$\frac{\partial}{\partial t}(\operatorname{ch})+\frac{\partial}{\partial x}(\operatorname{ch} u)+\frac{\partial}{\partial y}(\operatorname{ch} v)=0 ;$

where

- $h(x, y, t)$ is the thickness of the landslide perpendicular to the glide plane.

- $\boldsymbol{u}$ is the velocity vector with its components $(u, v)$ in accordance with $x$ and $y$ axis, respectively.

$-\kappa=1-\rho_{\mathrm{W}} / \rho_{\mathrm{s}}$ and $\rho_{\mathrm{s}}$ is the sediment density; $\rho_{\mathrm{s}}=$ $1450 \mathrm{~kg} \mathrm{~m}^{-3}$ according to in situ measurements (Lykousis et al., 2002) and $\rho_{\mathrm{w}}$ is the water density. Here we consider $\rho_{\mathrm{w}}=1000 \mathrm{~kg} \mathrm{~m}^{-3}$

- $c$ is the sediment concentration at a mean depth.

- $\boldsymbol{\theta}(x, y)$ is the local sliding angle with $\theta_{x}$ and $\theta_{y}$ its respective components in accordance with $x$ and $y$ axes. 


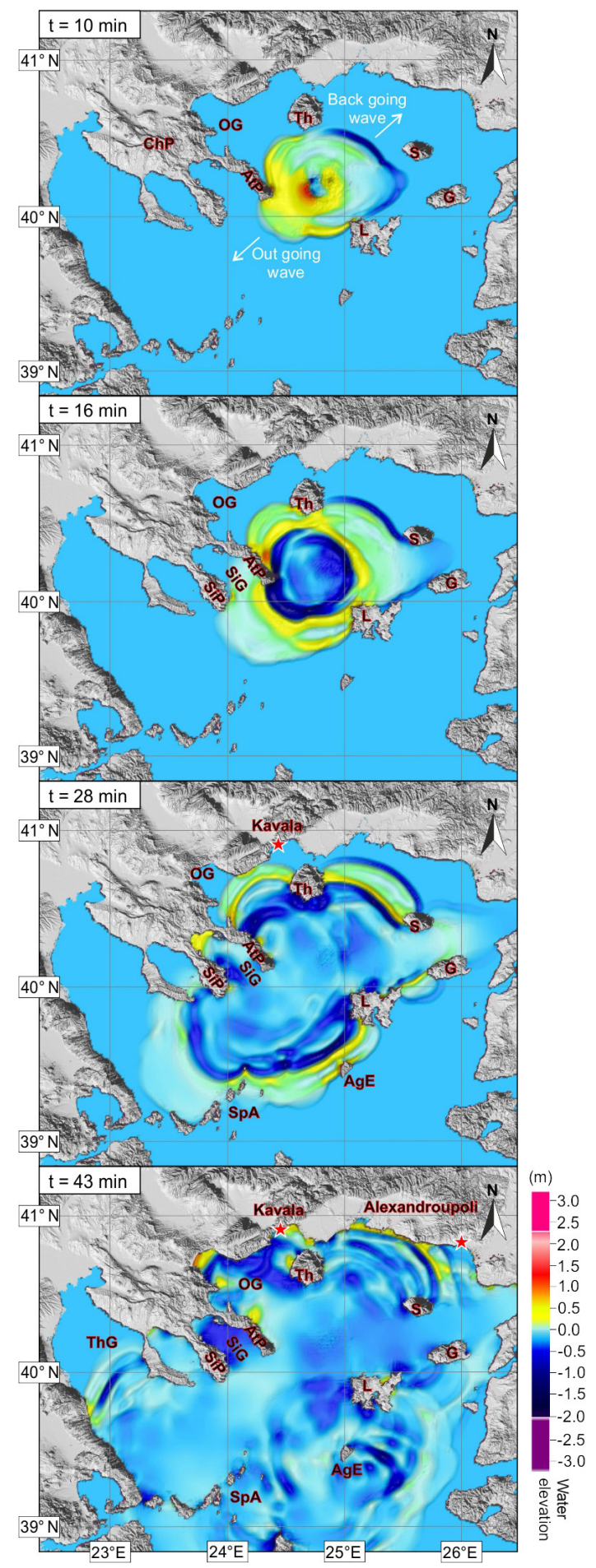

Figure 4. Tsunami propagation in the case of the first credible scenario. ( $e_{\mathrm{W}}$ of $10^{-3}$ and a basal friction angle of $1^{\circ}$; Table 1$)$. AgE is Agios Efstratios, AtP is Athos peninsula, G is Gokceada, L is Lemnos, OG is Gulf of Orfani, S is Samothrace, SiG is Sigitikos Gulf, SiP is Sithonia peninsula, SpA is Sporades archipelago, Th is Thasos and ThG is Thermaic Gulf.
- $\tau_{x z(z=0)}$ and $\tau_{y z(z=0)}$ are the shear stresses at the bed surface. The constitutive law governing granular flows is generally the Coulomb-type friction law defined in the $x$ direction by $\tau_{x z(z=0)}=\kappa g h \cos \theta \tan \phi \frac{u}{\|\boldsymbol{u}\|}$.

- $e_{\mathrm{w}}$ is the water entrainment coefficient $\left(e_{\mathrm{w}} \in[0,0.01]\right)$ (Fukushima et al., 1985; Kostic and Parker, 2006; Sequeiros et al., 2009). It corresponds to the dilution of the sedimentary mass by water incorporation at the interface between the slide and the water.

- $\alpha$ is a parameter characterizing the deviation of the velocity profile compared to a homogeneous distribution profile. Modelling landslide as a granular flow requires a linear profile and $\alpha=4 / 3$ (Heinrich et al., 2001).

The main limit of the simulation of a past submarine landslide is the impossibility of providing constraints on the pattern of velocity and acceleration of the slide from the geological record (Harbitz et al., 2006; Ma et al., 2013; Løvholt et al., 2015). We therefore consider scenarios in which slide velocities are compatible with the few constraints available from submarine cable breaks recorded in the 20th century, i.e., with mean velocity $<20-30 \mathrm{~m} \mathrm{~s}^{-1}$ and initial acceleration $<0.6 \mathrm{~m} \mathrm{~s}^{-2}$ (Heezen and Ewing, 1952; Mulder et al., 1997; Fine et al., 2005).

\subsection{Tsunami modelling}

Simulations of the tsunami waves are also based on the shallow-water approximation, which deals with the full interaction of landslide and water, including the deformation of the sediment body. Equations governing the landslide and the tsunami propagation are similar and are thus solved using the same Godunov-type scheme, extended to second order by using the concept of Vanleer (Alcrudo and GarciaNavarro, 1993; Mangeney et al., 2000). This model is particularly adapted to non-linear waves. The time history of sea-bottom deformation resulting from the landslide is introduced as a known forcing term $(\cos \theta)^{-1} \partial h / \partial t$ in the mass conservation equation of the tsunami model (Heinrich et al., 2000).

\section{Results}

\subsection{Elaboration of landslide and tsunami scenarios}

We simulate the tsunami that would be triggered in the present-day context by a slide similar to the Thasos slide. Credible scenarios are defined according to the range of parameters able to reproduce as closely as possible the firstorder morphology of the observed mass-transport deposit (i.e. fitting the following criteria: area of the deposit, volume, run-out). Credible scenarios (Table 1) are obtained for a range of basal friction angle $\phi$ between $1.5-1.8^{\circ}$ and an initial volume of failure of $1.85 \mathrm{~km}^{3}$ (Fig. 3). The selection 


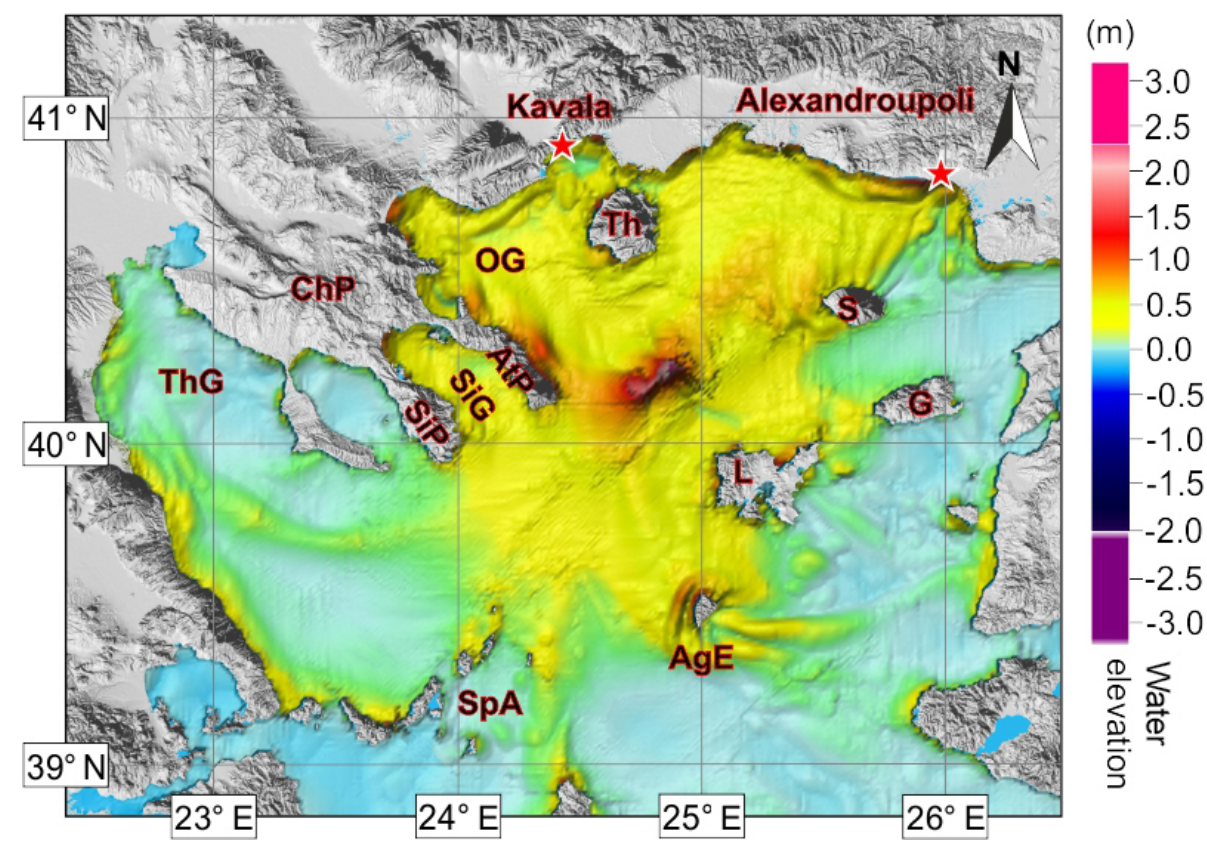

Figure 5. Figure of the maximum water elevation of the tsunami for the first credible scenario (Table 1). AgE is Agios Efstratios, AtP is Athos peninsula, G is Gokceada, L is Lemnos, OG is Gulf of Orfani, S is Samothrace, SiG is Sigitikos Gulf, SiP is Sithonia peninsula, SpA is Sporades archipelago, Th is Thasos, ThG is Thermaic Gulf.

of the most credible scenarios is buttressed on the basis of normalized inverse-distance weighting (Shepard, 1968) (Appendix A).

\subsection{Propagation of the tsunami potentially generated by the Thasos landslide}

For each selected scenario, we present maps of tsunami propagation at different, representative time steps $(10,16,28$ and 43 min; Figs. 4, 7). We also plot maps of the maximal water heights reached after a $2 \mathrm{~h}$ propagation time in the entire study area (Figs. 5, 8), which helps us to identify the bathymetric forcing effect on the tsunami elevation. The propagation of the tsunami at the source displays the same pattern in every scenario, typical of landslide-generated tsunami (Ward, 2001; Mohammed and Fritz, 2012; Ma et al., 2013). At the source, the incipient radiated wave has two peaks and one trough (Fig. 4). The water ahead of the front face of the slide (i.e. the outgoing wave) is pushed away, creating a leading positive wave in the slide direction (i.e. towards the Chalkidiki peninsula and the Thermaic Gulf). The trough following the crest is simultaneously created by the slide excavation and is followed by a large second positive peak created by the infilling of the trough. In contrast, the front of the wave propagating in the opposite direction of the slide (i.e. the backgoing wave) forms a trough propagating towards Alexandroupoli, followed by a second positive wave (Fig. 4). Among the 40 simulations carried out, we present two of them for which the deposit is well reproduced but leads to different tsunami elevations (Table 2).

\subsubsection{First scenario}

The first scenario is obtained for a basal friction angle $\phi$ of $1^{\circ}$ and a water entrainment coefficient of $10^{-3}$. Although the run-out of the modelled slide is slightly overestimated by $\sim 2 \mathrm{~km}$, the modelled volume is $3.7 \mathrm{~km}^{3}$, which compares closely to the observations (Fig. 3). The thickness of the modelled deposit, between 20 and $40 \mathrm{~m}$, is also in fair agreement with the observations from the seismic line crossing the Thasos slide (Fig. 3). In this scenario, the maximal velocity of the slide reaches the value of $30 \mathrm{~m} \mathrm{~s}^{-1}$ about $6 \mathrm{~min}$ after the slide beginning. During this phase, the acceleration of the slide is on the order of $0.2 \mathrm{~m} \mathrm{~s}^{-2}$. We describe the propagation of the tsunami following the timing of arrival of the leading wave at the coastline. At the source, the slide generates a tsunami with a maximal water elevation at $3.6 \mathrm{~m}$ (Fig. 5). After $8 \mathrm{~min}$ of propagation, the leading outgoing wave reaches the Chalkidiki peninsula and the island of Lemnos, with local amplification up to $1.25 \mathrm{~m}$. The front of the outgoing wave then sweeps the coast of the Athos peninsula towards the Gulf of Orfani. There, the leading wave reaches an elevation up to $1.20 \mathrm{~m}$ high after $\sim 40 \mathrm{~min}$ of propagation (Fig. 4). The tsunami then propagates into the multiple gulf formed by the finger-like pattern of the Chalkidiki peninsula (Fig. 4). The tsunami enters the Sigitikos Gulf after $\sim 15 \mathrm{~min}$ of propagation, then the Kassandra Gulf after 


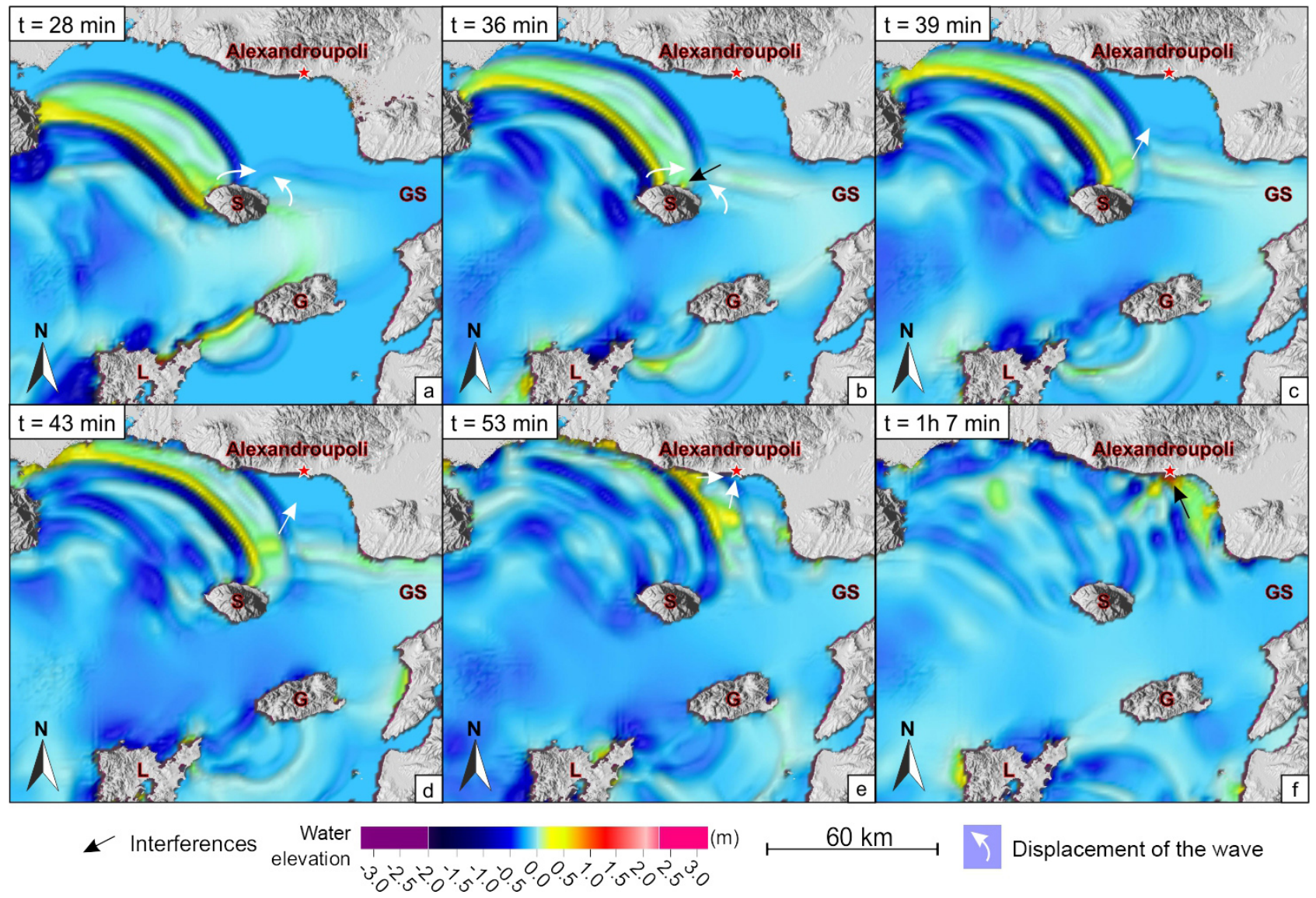

Figure 6. Tsunami propagation in the NE of the Aegean Sea: illustration of a complex system of amplification by interference for the first credible scenario (Table 1). GS is Gulf of Saros, G is Gokceada, L is Lemnos, OG is Gulf of Orfani and S is Samothrace. (a) The arrival in the south of Samothrace of wavefront, (b) rotation of the wavefront around Samothrace and development of constructive interferences in the north of the island, (c) recess of the wavefront of the island, (d) migration to the north for the new wavefront, (e) arrival of another front by the west, (f) constructive interferences in front of Alexandroupoli and formation of a wave of $1.65 \mathrm{~m} \mathrm{high}$.

$\sim 28$ min of propagation and eventually the Thermaic Gulf after $\sim 40 \mathrm{~min}$ of propagation. Tsunami elevation reaches $0.8-0.9 \mathrm{~m}$ in the Sigitikos Gulf, but remains below $0.4 \mathrm{~m}$ in the Kassandra Gulf (Fig. 4). The coastline running from the Sporades to the Thermaic Gulf is struck by a $\sim 0.5 \mathrm{~m}$ high tsunami (Fig. 4). A bathymetric trough related to a splay of the North Aegean Trough off Kassandra peninsula is responsible for the focalization and the amplification of the tsunami before it enters the Thermaic Gulf (Fig. 4). South of the source, the leading outgoing wave reaches the north of Lemnos after $\sim 10$ min of propagation and Agios Efstratios island at $t=26 \mathrm{~min}$ (Fig. 4), where complex phenomena of wave interactions lead to tsunami elevation on the order of $1.4 \mathrm{~m}$ at the coastline. The leading backgoing wave is split into several fronts propagating at different speeds when it reaches the Samothrace and Gokceada islands after $\sim 16$ min of propagation. A $1.65 \mathrm{~m}$ high tsunami strikes Alexandroupoli after $1 \mathrm{~h} 07 \mathrm{~min}$ of propagation (Fig. 4). The complex pattern of the Aegean coastline results in a complex pattern of wave interactions that either destroy or amplify the tsunami (Fig. 6).
Amplification through resonance is expected within the Sigitikos Bay, the Gulf of Orfani and the Pournias Bay, north of Lemnos (Fig. 4). Southeast of Agios Efstratios and north of Samothrace, we observe lineaments where the tsunami wave is amplified (on the order of $50 \mathrm{~cm}$ ), despite the lack of bathymetric feature that could explain local forcing. Constructive interferences between the waves that surrounded these islands may produce this amplification. At both locations, the leading wave is split into two wave fronts that rotate along the islands by a coastal attraction phenomenon, until the two wave fronts merge together, leading to wave amplification. For instance, the backgoing wave of the tsunami is split into two wave fronts when it strikes Samothrace at $t=28 \mathrm{~min}$ (Fig. 6). After their propagation around the island, both fronts collide at $t=36 \mathrm{~min}$, which results in constructive interferences that amplify the wave up to $\sim 0.5$ $0.6 \mathrm{~m}$. A second positive wave front, which has been amplified along the Thracian coast (Fig. 6 at $43 \mathrm{~min}$ ), collides with the backgoing wave front formed east of Samothrace. This interference cancels the negative polarity of the backgoing 
wave and even amplifies the tsunami front up to $1.65 \mathrm{~m}$ at Alexandroupoli.

\subsubsection{Second scenario}

The second selected scenario is obtained for a basal friction angle $\phi$ of $1.5^{\circ}$ and a water entrainment coefficient $e_{\mathrm{w}}$ of $5.10^{-4}$. In this model, the area of the mass-transport deposit is larger than the observations, resulting in an overestimated but still reasonable volume of $4.1 \mathrm{~km}^{3}$ (Fig. 3). In this case, the maximal velocity of the slide reaches $25 \mathrm{~m} \mathrm{~s}^{-1}$ about $3 \mathrm{~min}$ after the slide triggering. During this phase, the slide acceleration is on the order of $\sim 0.15 \mathrm{~m} \mathrm{~s}^{-2}$. This second scenario leads to the same timing and mode of propagation of the tsunami, with similar processes of wave amplifications and interactions around the islands of Agios Efstratios and Samothrace (Fig. 7). However, the tsunami elevation is less important everywhere than in the first scenario. The maximum water elevation is reduced at $\sim 85 \mathrm{~cm}$ along the Chalkidiki peninsula, at $\sim 1.10 \mathrm{~m}$ at Alexandroupoli and around $50 \mathrm{~cm}$ at Agios Efstratios and north of Lemnos. Amplification within the bays of Sigitikos, Kassandra and the Gulf of Thermaikos is also reduced, with water heights less than $20 \mathrm{~cm}$ (Fig. 8).

\section{Discussion}

Our simulations were able to strikingly reproduce the firstorder morphological characteristics of the Thassos slide, using basic granular flow behaviour governed by a simple Coulomb friction law at the glide plane. Therefore, the selected range of physical parameters used for the granular flow modelling and the resulting tsunami are considered realistic. Compared to previous studies (Karambas and Hasiotis, 2012), the advantage of our approach is the coupling between the dynamic of the slide, the formation of the tsunami and its propagation.

The results of our simulations show that the Thasos slide has probably been tsunamigenic. If a similar slide occurs at the current sea level, the areas of Alexandroupoli (57812 inhabitants in 2011 according to the Hellenic Statistical Authority), the Chalkidiki peninsula and Agios Efstratios would be the most threatened, with tsunami elevations at the coastline ranging between 1 and $2 \mathrm{~m}$ according to the model parameters.

The tsunami strikes most of the coastlines of the northern Aegean Sea after less than $1 \mathrm{~h}$ of propagation (Table 2). The Athos peninsula is reached after just $10 \mathrm{~min}$, but is not densely populated and the topography does not allow large run-up distances. The geomorphological context of the Thassos slide is similar to the slide at the origin of the Papua New Guinea tsunami in 1998 (roughly the same volume, slope and distance to the coastline), but the numerous interactions between waves due to the numerous bays and islands make

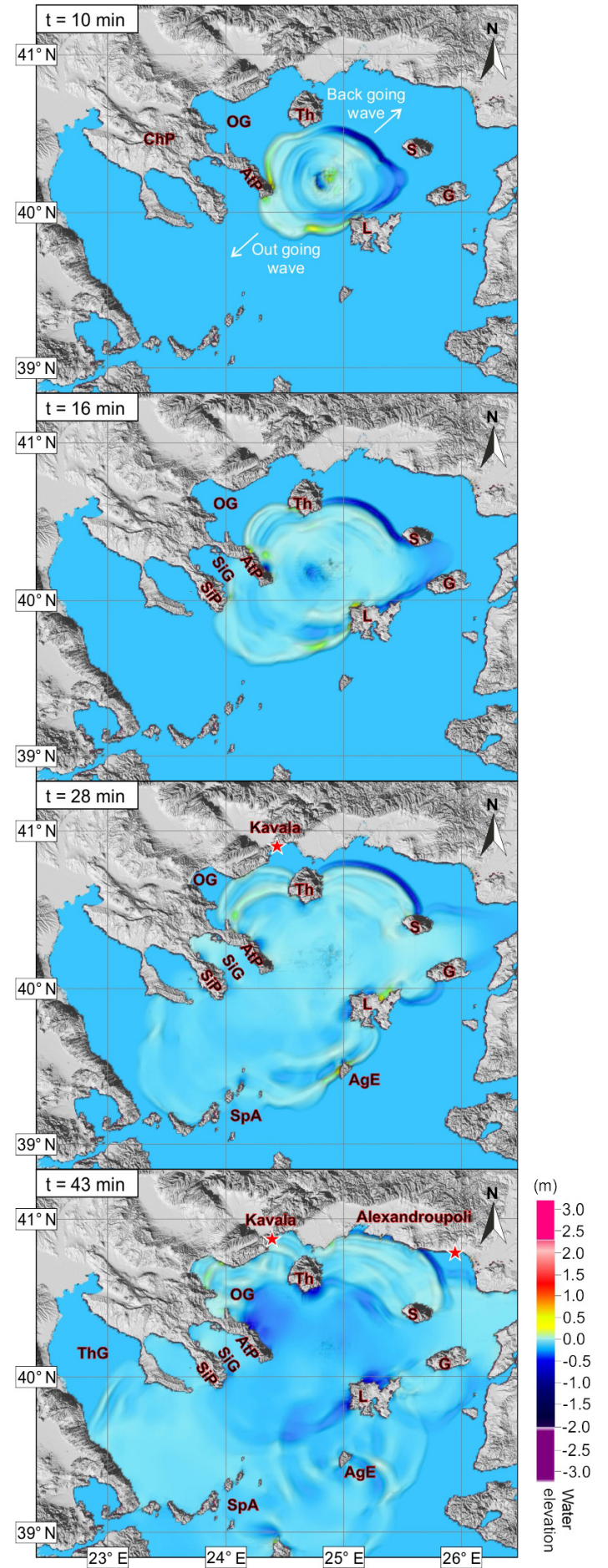

Figure 7. Tsunami propagation in the case of the second credible scenario $\left(e_{\mathrm{W}}\right.$ of $5 \times 10^{-4}$ and a basal friction angle of $1.5^{\circ}$; Table 1$)$. $\mathrm{AgE}$ is Agios Efstratios, AtP is Athos peninsula, G is Gokceada, L is Lemnos, OG is Gulf of Orfani, $\mathrm{S}$ is Samothrace, $\mathrm{SiG}$ is Sigitikos Gulf, SiP is Sithonia peninsula, SpA is Sporades archipelago, Th is Thasos and ThG is Thermaic Gulf. 


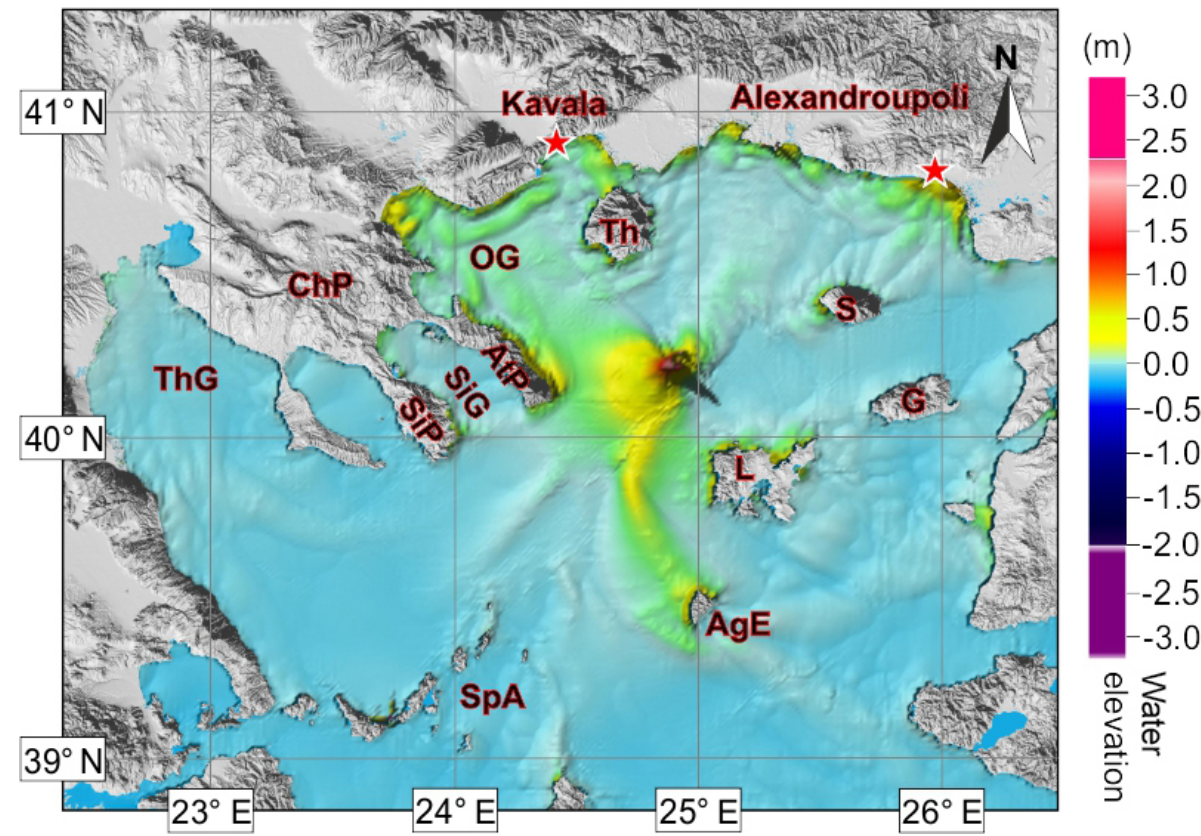

Figure 8. Maximum water elevation of the tsunami for the second credible scenario (Table 1). AgE is Agios Efstratios, AtP is Athos peninsula, G is Gokceada, L is Lemnos, OG is Gulf of Orfani, S is Samothrace, SiG is Sigitikos Gulf, SiP is Sithonia peninsula, SpA is Sporades archipelago, Th is Thasos and ThG is Thermaic Gulf.

the expected height of the tsunami at the Aegean coastline lower. The tsunami simulations have some limits. The first one is the lack of high-resolution bathymetry along the coast, which does not allow for an accurate computation of the flooding on land. It remains unknown whether local bathymetric features or harbours would result in further amplification or dispersion of the tsunami wave. This is especially critical for the numerous gulfs (Orfani, Sigitikos and Kassandra) for which resonance is expected. Run-up values being often more important than the water height calculated a few kilometres from the coastline (Synolakis, 1987), the computed tsunami elevations at the coastline should be considered to be the minimum values of the actual run-up. Moreover, the initial slide acceleration and its speed strongly impinge on the initial pattern of the tsunami, including the pattern of short wavelengths, and therefore on the subsequent frequency dispersion (Haugen et al., 2005). Even if the modelled values of slide velocity and acceleration fit with values measured on slides triggered in the 20th-21st centuries (Heezen and Ewing, 1952; Mulder et al., 1997; Pope et al., 2016), geological records are not sufficient to determine these parameters for the Holocene period.

A second-order source of simplification is the nondispersive numerical model that is not able to account for frequency dispersion inherent in tsunamis with short wavelengths. However, the density of the mobilized sediments is quite low $\left(\sim 1500 \mathrm{~kg} \mathrm{~m}^{-3}\right)$. Frequency dispersion at the source is expected to be negligible for this range of densities (Ma et al., 2013).

\section{Conclusion}

The results of our simulations show that the expected tsunami waves from the Thasos slide are higher $(165 \mathrm{~cm}$ for Alexandroupoli or $145 \mathrm{~cm}$ for the coasts of Agios Efstratios, Sporades archipelago and Athos peninsula) than values expected in the case of an earthquake along the North Anatolian Fault and higher than run-up values (between 20 and $50 \mathrm{~cm}$ south of Thessaloniki) documented from tsunami deposits in the Thermaic Gulf (Reicherter et al., 2010). The study highlights the need to build a comprehensive map of the distribution of landslides within the North Aegean Trough, as well as a full quantification of their volumes, to better estimate the variety of tsunami scenarios in the area. This discrepancy between earthquake and landslide recurrence asks what the response of sedimentary systems is to ground shaking. The tsunami hazard related to submarine landslides similar to Thassos is less severe than tsunami associated with landslides triggered during the 1956 Amorgos event (Perissoratis and Papadopoulos, 1999; Okal et al., 2009) or tsunamis triggered during or subsequent to volcanic events (e.g. Santorini in the Bronze age, Novikova et al., 2011).

Data availability. Bathymetry data are available at http://portal. emodnet-bathymetry.eu/ (last access: 15 January 2019). 


\section{Appendix A: Selection of tsunami scenario}

In order to quantify the gap between landslide simulation results and data from bathymetry and seismic profiles we used a normalized inverse-distance weighting function. Thereby we define a weight function $\omega$ as

$\omega=\sum_{k=1}^{4} \frac{1}{d_{k}\left(x_{k}, x_{k}^{t h}\right)^{p}}$,

where

- $x_{k}$ are parameters used for determined the differences between the numerical simulation and the bathymetry. We used for $x_{k}$ : (1) the sliding direction, (2) the total surface of deposit, (3) the amplitude of the discontinuity in the thickness of sediments between units 1 and 2 (Fig. 2) and (4) the final volume of the deposit.

- $x_{k}^{\text {th }}$ are the used observable parameters from the bathymetry and the seismic profiles corresponding to $x_{k}$.

- $d_{k}\left(x_{k}, x_{k}^{t h}\right)$ are distance functions between $x_{k}$ and $x_{k}^{t h}$. Here we define $d_{k}$ as $d_{k}=\left|x_{k}^{t h}-x_{k}\right|$.

- $p$ is a real positive number, called the power parameter. If $p>1$, the contribution in $\omega$ of the small distance is amplified (here we used $p=1$ ).

The higher the $\omega$, the closer the scenario is to bathymetry and seismic data. The function $\omega$ is calculated for all scenarios and allows us to highlight the two scenarios presented in this study. The computation of $\omega$ for the two credible scenarios gives $\omega=181.52$ and $\omega=2.56$ (Fig. 3). 
Supplement. The supplement related to this article is available online at: https://doi.org/10.5194/nhess-19-121-2019-supplement.

Competing interests. The authors declare that they have no conflict of interest.

Acknowledgements. We acknowledge the support of the "Yves Rocard" Joint Laboratory between the École Normale Supérieure, the Comissariat à l'Énergie Atomique, and the CNRS.

Edited by: Oded Katz

Reviewed by: Kiichiro Kawamura

\section{References}

Alcrudo, F. and Garcia-Navarro, P.: A high-resolution Godunovtype scheme in finite volumes for the $2 \mathrm{D}$ shallow-water equations, Int. J. Numer. Meth. Fl., 16, 489-505, 1993.

Alpar, B., Yalciner, A. C., Imamura, F., and Synolakis, C. E.: Determination of probable underwater failures and modeling of tsunami propagation in the Sea of Marmara, in: Proceedings of the International Tsunami Symposium ITS, 535-544, 2001.

Altinok, Y., Alpar, B., Özer, N., and Aykurt, H.: Revision of the tsunami catalogue affecting Turkish coasts and surrounding regions, Nat. Hazards Earth Syst. Sci., 11, 273-291, https://doi.org/10.5194/nhess-11-273-2011, 2011.

Armijo, R., Meyer, B., Hubert, A., and Barka, A.: Westward propagation of the North Anatolian fault into the northern Aegean: Timing and kinematics, Geology, 27, 267-270, 1999.

Beck, C., de Lépinay, B. M., Schneider, J.-L., Cremer, M., Çă̆atay, N., Wendenbaum, E., Boutareaud, S., Ménot, G., Schmidt, S., Weber, O., Eris, K., Armijo, R., Meyer, B., Pondard, N., Gutscher, M.-A., Cruise Party MARMACORE, Turon, J. L., Labeyrie, L., Cortijo, E., Gallet, Y., Bouquerel, H., Gorur, N., Gervais, A., Castera, M. H., Londeix, L., de Rességuier, A., and Jaouen, A: Late Quaternary co-seismic sedimentation in the Sea of Marmara's deep basins, Sediment. Geol., 199, 65-89, 2007.

Becker, J., Sandwell, D., Smith, W., Braud, J., Binder, B., Depner, J., Fabre, D., Factor, J., Ingalls, S., Kim, S., Ladner, R., Marks, K., Nelson, S., Pharaoh, A., Trimmer, J., Von Rosenberg, J., Wallace, G., Weatherall, P.: Global bathymetry and elevation data at 30 arc seconds resolution: SRTM30_PLUS, Mar. Geod., 32, 355-371, 2009.

Beniest, A., Brun, J.-P., Gorini, C., Crombez, V., Deschamps, R., Hamon, Y., and Smit, J.: Interaction between trench retreat and anatolian escape as recorded by neogene basins in the northern Aegean Sea, Mar. Petrol. Geol., 77, 30-42, 2016.

Brooks, M. and Ferentinos, G.: Structure and evolution of the Sporadhes basin of the North Aegean trough, northern Aegean Sea, Tectonophysics, 68, 15-30, 1980.

Brun, J.-P., Faccenna, C., Gueydan, F., Sokoutis, D., Philippon, M., Kydonakis, K., and Gorini, C.: The two-stage Aegean extension, from localized to distributed, a result of slab rollback acceleration, Can. J. Earth Sci., 53, 1142-1157, 2016.

Bulut, F., Özener, H., Doğru, A., Aktuğ, B., and Yaltırak, C.: Structural setting along the Western North Ana- tolian Fault and its influence on the 2014 North Aegean Earthquake (Mw 6.9), Tectonophysics, 382-394, https://doi.org/10.1016/j.tecto.2018.07.006, 2018.

Canals, M., Lastras, G., Urgeles, R., Casamor, J., Mienert, J., Cattaneo, A., De Batist, M., Haflidason, H., Imbo, Y., Laberg, J., Locat, J., Long, D., Longva, O., Masson, D. G., Sultan, N., Trincardi, F., and Bryn, P.: Slope failure dynamics and impacts from seafloor and shallow sub-seafloor geophysical data: case studies from the COSTA project, Mar. Geol., 213, 9-72, 2004.

Chaytor, J. D., Uri, S., Solow, A. R., and Andrews, B. D.: Size distribution of submarine landslides along the US Atlantic margin, Mar. Geol., 264, 16-27, 2009.

Drab, L., Hubert Ferrari, A., Schmidt, S., and Martinez, P.: The earthquake sedimentary record in the western part of the Sea of Marmara, Turkey, Nat. Hazards Earth Syst. Sci., 12, 1235-1254, https://doi.org/10.5194/nhess-12-1235-2012, 2012.

Drab, L., Hubert-Ferrari, A., Schmidt, S., Martinez, P., Carlut, J., and El Ouahabi, M.: Submarine earthquake history of the Çınarcrk segment of the North Anatolian Fault in the Marmara Sea, Turkey, B. Seismol. Soc. Am., 105, 622-645, 2015.

Faccenna, C., Bellier, O., Martinod, J., Piromallo, C., and Regard, V.: Slab detachment beneath eastern Anatolia: A possible cause for the formation of the North Anatolian fault, Earth Planet. Sc. Lett., 242, 85-97, 2006.

Ferentinos, G., Brooks, M., and Collins, M.: Gravity-induced deformation on the north flank and floor of the Sporadhes Basin of the North Aegean Sea Trough, Mar. Geol., 44, 289-302, 1981.

Ferentinos, G., Georgiou, N., Christodoulou, D., Geraga, M., and Papatheodorou, G.: Propagation and termination of a strike slip fault in an extensional domain: The westward growth of the North Anatolian Fault into the Aegean Sea, Tectonophysics, 745, 183-195, https://doi.org/10.1016/j.tecto.2018.08.003, 2018.

Fine, I., Rabinovich, A., Bornhold, B., Thomson, R., and Kulikov, E.: The Grand Banks landslide-generated tsunami of November 18, 1929: preliminary analysis and numerical modeling, Mar. Geol., 215, 45-57, 2005.

Fukushima, Y., Parker, G., and Pantin, H.: Prediction of ignitive turbidity currents in Scripps Submarine Canyon, Mar. Geol., 67, 55-81, 1985.

Grall, C., Henry, P., Tezcan, D., de Lepinay, B. M., Bécel, A., Géli, L., Rudkiewicz, J.-L., Zitter, T., and Harmegnies, F.: Heat flow in the Sea of Marmara Central Basin: Possible implications for the tectonic evolution of the North Anatolian fault, Geology, 40, 3-6, 2012.

Grall, C., Henry, P., Thomas, Y., Westbrook, G., Çağatay, M., Marsset, B., Saritas, H., Çifçi, G., and Geli, L.: Slip rate estimation along the western segment of the Main Marmara Fault over the last $405-490 \mathrm{ka}$ by correlating mass transport deposits, Tectonics, 32, 1587-1601, 2013.

Hampton, M. A., Lee, H. J., and Locat, J.: Submarine landslides, Rev. Geophys., 34, 33-59, 1996.

Harbitz, C. B., Løvholt, F., Pedersen, G., and Masson, D. G.: Mechanisms of tsunami generation by submarine landslides: a short review, Norw. J. Geol., 86, 255-264, 2006.

Harbitz, C. B., Løvholt, F., and Bungum, H.: Submarine landslide tsunamis: how extreme and how likely?, Nat. Hazards, 72, 1341$1374,2014$. 
Haugen, K. B., Løvholt, F., and Harbitz, C. B.: Fundamental mechanisms for tsunami generation by submarine mass flows in idealised geometries, Mar. Petrol. Geol., 22, 209-217, 2005.

Hébert, H., Schindele, F., Altinok, Y., Alpar, B., and Gazioglu, C.: Tsunami hazard in the Marmara Sea (Turkey): a numerical approach to discuss active faulting and impact on the Istanbul coastal areas, Mar. Geol., 215, 23-43, 2005.

Heezen, B. C. and Ewing, M.: Turbidity currents and submarine slumps, and the 1929 Grand Banks earthquake, Am. J. Sci., 250, 849-873, 1952.

Heinrich, P., Piatanesi, A., Okal, E., and Hébert, H.: Near-field modeling of the July 17, 1998 tsunami in Papua New Guinea, Geophys. Res. Lett., 27, 3037-3040, 2000.

Heinrich, P., Piatanesi, A., and Hebert, H.: Numerical modelling of tsunami generation and propagation from submarine slumps: the 1998 Papua New Guinea event, Geophys. J. Int., 145, 97-111, 2001.

Hubert-Ferrari, A., Barka, A., Jacques, E., Nalbant, S. S., Meyer, B., Armijo, R., Tapponnier, P., and King, G. C. P.: Seismic hazard in the Marmara Sea region following the 17 August 1999 Izmit earthquake, Nature, 404, p. 269, 2000.

Hubert-Ferrari, A., King, G., Van Der Woerd, J., Villa, I., Altunel, E., and Armijo, R.: Long-term evolution of the North Anatolian Fault: new constraints from its eastern termination, Geol. Soc. Sp., 311, 133-154, 2009.

Iacono, C. L., Gràcia, E., Ranero, C. R., Emelianov, M., Huvenne, V. A., Bartolomé, R., Booth-Rea, G., Prades, J., Ambroso, S., Dominguez, C., Grinyó, J., Rubio, E., and Torrent, J.: The West Melilla cold water coral mounds, Eastern Alboran Sea: Morphological characterization and environmental context, Deep-Sea Res. Pt II, 99, 316-326, 2014.

Iglesias, O., Lastras, G., Canals, M., Olabarrieta, M., Gonzalez, M., Aniel-Quiroga, Í., Otero, L., Duran, R., Amblas, D., Casamor, J. L., Tahchi, E., Tinti, S., and De Mol, B.: The BIG'95 submarine landslide-generated tsunami: a numerical simulation, J. Geol., 120, 31-48, 2012.

İşler, E., Aksu, A., Yaltırak, C., and Hiscott, R.: Seismic stratigraphy and Quaternary sedimentary history of the northeast Aegean Sea, Mar. Geol., 254, 1-17, 2008.

Jiang, L. and LeBlond, P. H.: Numerical modeling of an underwater Bingham plastic mudslide and the waves which it generates, J. Geophys. Res.-Oceans, 98, 10303-10317, 1993.

Jolivet, L. and Brun, J.-P.: Cenozoic geodynamic evolution of the Aegean, Int. J. Earth Sci., 99, 109-138, 2010.

Jolivet, L. and Faccenna, C.: Mediterranean extension and the Africa-Eurasia collision, Tectonics, 19, 1095-1106, 2000.

Jolivet, L., Faccenna, C., Huet, B., Labrousse, L., Le Pourhiet, L., Lacombe, O., Lecomte, E., Burov, E., Denele, Y., Brun, J.-P., Philippon, M., Paul, A., Salaün, G., Karabulut, H., Piromallo, C., Monié, P., Gueydan, F., Okay, A. I., Oberhänsli, R., Pourteau, A., Augier, R., Gadenne, L., and Driussi, O.: Aegean tectonics: Strain localisation, slab tearing and trench retreat, Tectonophysics, 597, 1-33, 2013.

Jolivet, L., Menant, A., Sternai, P., Rabillard, A., Arbaret, L., Augier, R., Laurent, V., Beaudoin, A., Grasemann, B., Huet, B., Labrousse, L., and Le Pourhiet, L.: The geological signature of a slab tear below the Aegean, Tectonophysics, 659, 166-182, 2015 .
Karambas, T. V. and Hasiotis, T.: A Study of Tsunamis Generated by Underwater Landslides in the Aegean Sea, in: The Twentysecond International Offshore and Polar Engineering Conference, International Society of Offshore and Polar Engineers, 2012.

Katz, O., Reuven, E., and Aharonov, E.: Submarine landslides and fault scarps along the eastern Mediterranean Israeli continentalslope, Mar. Geol., 369, 100-115, 2015.

Kostic, S. and Parker, G.: The response of turbidity currents to a canyon-fan transition: internal hydraulic jumps and depositional signatures, J. Hydraul. Res., 44, 631-653, 2006.

Kurt, H., Demirbağ, E., and Kuşçu, İ.: Active submarine tectonism and formation of the Gulf of Saros, Northeast Aegean Sea, inferred from multi-channel seismic reflection data, Mar. Geol., 165, 13-26, 2000.

Labbé, M., Donnadieu, C., Daubord, C., and Hébert, H.: Refined numerical modeling of the 1979 tsunami in Nice (French Riviera): Comparison with coastal data, J. Geophys. Res.-Earth, 117,https://doi.org/10.1029/2011JF001964, 2012.

Lafuerza, S., Sultan, N., Canals, M., Lastras, G., Cattaneo, A., Frigola, J., Costa, S., and Berndt, C.: Failure mechanisms of Ana Slide from geotechnical evidence, Eivissa Channel, Western Mediterranean Sea, Mar. Geol., 307, 1-21, 2012.

Laigle, M., Hirn, A., Sachpazi, M., and Roussos, N.: North Aegean crustal deformation: an active fault imaged to $10 \mathrm{~km}$ depth by reflection seismic data, Geology, 28, 71-74, 2000.

Le Pichon, X. and Kreemer, C.: The Miocene-to-present kinematic evolution of the eastern Mediterranean and Middle East and its implications for dynamics, Annu. Rev. Earth Pl. Sc., 38, 323351, 2010.

Le Pichon, X., Şengör, A., Demirbağ, E., Rangin, C., Imren, C., Armijo, R., Görür, N., Çağatay, N., De Lepinay, B. M., Meyer, B., Saatçilar, R., and Tok, B.: The active main Marmara fault, Earth Planet. Sc. Lett., 192, 595-616, 2001.

Le Pichon, X., Imren, C., Rangin, C., Şengör, A. C., and Siyako, M.: The South Marmara Fault, Int. J. Earth Sci., 103, 219-231, 2014.

Le Pichon, X., Şengör, A. C., Kende, J., İmren, C., Henry, P., Grall, C., and Karabulut, H.: Propagation of a strike-slip plate boundary within an extensional environment: the westward propagation of the North Anatolian Fault, Can. J. Earth Sci., 53, 1416-1439, 2015.

Løvholt, F., Pedersen, G., Harbitz, C. B., Glimsdal, S., and Kim, J.: On the characteristics of landslide tsunamis, Phil. Trans. R. Soc. A, 373, https://doi.org/10.1098/rsta.2014.0376, 2015.

Lykousis, V., Roussakis, G., Alexandri, M., Pavlakis, P., and Papoulia, I.: Sliding and regional slope stability in active margins: North Aegean Trough (Mediterranean), Mar. Geol., 186, 281298, 2002.

Ma, G., Kirby, J. T., and Shi, F.: Numerical simulation of tsunami waves generated by deformable submarine landslides, Ocean Model., 69, 146-165, 2013.

Ma, K.-F., Satake, K., and Kanamori, H.: The origin of the tsunami excited by the 1989 Loma Prieta Earthquake-Faulting or slumping?, Geophys. Res. Lett., 18, 637-640, 1991.

Macías, J., Vázquez, J., Fernández-Salas, L., González-Vida, J., Bárcenas, P., Castro, M., Díaz-del Río, V., and Alonso, B.: The Al-Borani submarine landslide and associated tsunami. A modelling approach, Mar. Geol., 361, 79-95, 2015. 
Mangeney, A., Heinrich, P., and Roche, R.: Analytical solution for testing debris avalanche numerical models, Pure Appl. Geophys., 157, 1081-1096, 2000.

Masson, D., Harbitz, C., Wynn, R., Pedersen, G., and Løvholt, F.: Submarine landslides: processes, triggers and hazard prediction, Phil. Transa. R. Soc. A, 364, 2009-2039, 2006.

Mathes-Schmidt, M., Papanikolaou, J., and Reicherter, K.: Event deposits in the Eastern Thermaikos Gulf and Kassandra Peninsula (Northern Greece) and evidence of the 479 BC Herodotustsunami, available at: http://paleoseismicity.org (last access: 9 September 2017), 2009.

McAdoo, B., Pratson, L., and Orange, D.: Submarine landslide geomorphology, US continental slope, Mar. Geol., 169, 103-136, 2000.

McHugh, C. M., Seeber, L., Cormier, M.-H., Dutton, J., Cagatay, N., Polonia, A., Ryan, W. B., and Gorur, N.: Submarine earthquake geology along the North Anatolia Fault in the Marmara Sea, Turkey: a model for transform basin sedimentation, Earth Planet. Sc. Lett., 248, 661-684, 2006.

McNeill, L., Mille, A., Minshull, T., Bull, J., Kenyon, N., and Ivanov, M.: Extension of the North Anatolian Fault into the North Aegean Trough: Evidence for transtension, strain partitioning, and analogues for Sea of Marmara basin models, Tectonics, 23, https://doi.org/10.1029/2002TC001490, 2004.

Meghraoui, M., Aksoy, M. E., Akyüz, H. S., Ferry, M., Dikbaş, A., and Altunel, E.: Paleoseismology of the North Anatolian fault at Güzelköy (Ganos segment, Turkey): Size and recurrence time of earthquake ruptures west of the Sea of Marmara, Geochem. Geophy., Geosy., 13, https://doi.org/10.1029/2011GC003960, 2012.

Mohammed, F. and Fritz, H. M.: Physical modeling of tsunamis generated by three-dimensional deformable granular landslides, J. Geophys. Res.-Oceans, 117, https://doi.org/10.1029/2011JC007850, 2012.

Mulder, T., Savoye, B., and Syvitski, J.: Numerical modelling of a mid-sized gravity flow: the 1979 Nice turbidity current (dynamics, processes, sediment budget and seafloor impact), Sedimentology, 44, 305-326, 1997.

Mulder, T., Gonthier, E., Lecroart, P., Hanquiez, V., Marches, E., and Voisset, M.: Sediment failures and flows in the Gulf of Cadiz (eastern Atlantic), Mar. Petrol. Geol., 26, 660-672, 2009.

Müller, M., Geiger, A., Kahle, H.-G., Veis, G., Billiris, H., Paradissis, D., and Felekis, S.: Velocity and deformation fields in the North Aegean domain, Greece, and implications for fault kinematics, derived from GPS data 1993-2009, Tectonophysics, 597, 34-49, 2013.

Novikova, T., Papadopoulos, G., and McCoy, F.: Modelling of tsunami generated by the giant late Bronze Age eruption of Thera, South Aegean Sea, Greece, Geophys. J. Int., 186, 665680, 2011.

Okal, E. A.: The quest for wisdom: lessons from 17 tsunamis, 2004-2014, Phil. Trans. R. Soc. A, 373, https://doi.org/10.1098/rsta.2014.0370, 2015.

Okal, E. A. and Synolakis, C. E.: A theoretical comparison of tsunamis from dislocations and landslides, Pure Appl. Geophys., 160, 2177-2188, 2003.

Okal, E. A., Synolakis, C. E., Uslu, B., Kalligeris, N., and Voukouvalas, E.: The 1956 earthquake and tsunami in Amorgos, Greece, Geophys. J. Int., 178, 1533-1554, 2009.
Özeren, M. S., Çağatay, M. N., Postacıoğlu, N., Şengör, A. C., Görür, N., and Eriş, K.: Mathematical modelling of a potential tsunami associated with a late glacial submarine landslide in the Sea of Marmara, Geo-Mar. Lett., 30, 523-539, 2010.

Palomino, D., Vázquez, J.-T., Somoza, L., León, R., LópezGonzález, N., Medialdea, T., Fernández-Salas, L.-M., González, F.-J., and Rengel, J. A.: Geomorphological features in the southern Canary Island Volcanic Province: The importance of volcanic processes and massive slope instabilities associated with seamounts, Geomorphology, 255, 125-139, 2016.

Papadopoulos, G. A., Gràcia, E., Urgeles, R., Sallares, V., De Martini, P. M., Pantosti, D., González, M., Yalciner, A. C., Mascle, J., Sakellariou, D., Salamon, A., Tinti, S., Karastathis, V., Fokaefs, A., Camerlenghi, A., Novikova, T., and Papageorgiou, A.: Historical and pre-historical tsunamis in the Mediterranean and its connected seas: Geological signatures, generation mechanisms and coastal impacts, Mar. Geol., 354, 81-109, 2014.

Papanikolaou, D., Alexandri, M., Nomikou, P., and Ballas, D.: Morphotectonic structure of the western part of the North Aegean Basin based on swath bathymetry, Mar. Geol., 190, 465-492, 2002.

Papatheodorou, G., Hasiotis, T., and Ferentinos, G.: Gas-charged sediments in the Aegean and Ionian Seas, Greece, Mar. Geol., 112, 171-184, 1993.

Perissoratis, C. and Papadopoulos, G.: Sediment instability and slumping in the southern Aegean Sea and the case history of the 1956 tsunami, Mar. Geol., 161, 287-305, 1999.

Perouse, E., Chamot-Rooke, N., Rabaute, A., Briole, P., Jouanne, F., Georgiev, I., and Dimitrov, D.: Bridging onshore and offshore present-day kinematics of central and eastern Mediterranean: implications for crustal dynamics and mantle flow, Geochem. Geophy. Geosy., 13, https://doi.org/10.1029/2012GC004289, 2012.

Piper, D. J. and Perissoratis, C.: Late Quaternary Sedimentation on the North Aegean Continental Margin, Greece, AAPG Bull., 75, 46-61, 1991.

Pope, E., Talling, P., Urlaub, M., Hunt, J., Clare, M., and Challenor, P.: Are large submarine landslides temporally random or do uncertainties in available age constraints make it impossible to tell?, Mar. Geol., 369, 19-33, 2015.

Pope, E. L., Talling, P. J., and Carter, L.: Which earthquakes trigger damaging submarine mass movements: Insights from a global record of submarine cable breaks?, Mar. Geol., 384, 131-146, 2016.

Reicherter, K., Papanikolaou, I., Roger, J., Mathes-Schmidt, M., Papanikolaou, D., Rössler, S., Grützner, C., and Stamatis, G.: Holocene tsunamigenic sediments and tsunami modelling in the Thermaikos Gulf area (northern Greece), Z. Geomorphol. Supp., 54, 99-125, 2010.

Reilinger, R., McClusky, S., Vernant, P., Lawrence, S., Ergintav, S., Cakmak, R., Ozener, H., Kadirov, F., Guliev, I., Stepanyan, R., Nadariya, M., Hahubia, G., Mahmoud, S., Sakr, K., ArRajehi, A., Paradissis, D., Al-Aydrus, A., Prilepin, M., Guseva, T., Evren, E., Dmitrotsa, A., Filikov, S. V., Gomez, F., Al-Ghazzi, R., and Karam, G.: GPS constraints on continental deformation in the Africa-Arabia-Eurasia continental collision zone and implications for the dynamics of plate interactions, J. Geophys. Res.-Sol. Ea., 111, https://doi.org/10.1029/2005JB004051, 2006.

Reilinger, R., McClusky, S., Paradissis, D., Ergintav, S., and Vernant, P.: Geodetic constraints on the tectonic evolution of the 
Aegean region and strain accumulation along the Hellenic subduction zone, Tectonophysics, 488, 22-30, 2010.

Rodriguez, M., Fournier, M., Chamot-Rooke, N., Huchon, P., Zaragosi, S., and Rabaute, A.: Mass wasting processes along the Owen Ridge (northwest Indian Ocean), Mar. Geol., 326, 80-100, 2012.

Rodriguez, M., Chamot-Rooke, N., Hébert, H., Fournier, M., and Huchon, P.: Owen Ridge deep-water submarine landslides: implications for tsunami hazard along the Oman coast, Nat. Hazards Earth Syst. Sci., 13, 417-424, https://doi.org/10.5194/nhess-13417-2013, 2013.

Rodriguez, M., Maleuvre, C., Jollivet-Castelot, M., d'Acremont, E., Rabaute, A., Lafosse, M., Ercilla, G., Vázquez, J.-T., Alonso, B., and Ammar, A.: Tsunamigenic submarine landslides along the Xauen-Tofiño banks in the Alboran Sea (Western Mediterranean Sea), Geophys. J. Int., 209, 266-281, 2017.

Rodriguez, M., Sakellariou, D., Gorini, C., Chamot-Rooke, N., d'Acremont, E., Nercessian, A., Tsampouraki Kraounaki, K., Oregioni, D., Delescluse, M., and Janin, A.: Seismic profiles across the North Anatolian Fault in the Aegean Sea, in: EGU General Assembly Conference Abstracts, vol. 20, p. 7426, 2018.

Roussos, N. and Lyssimachou, T.: Structure of the Central North Aegean Trough: an active strike-slip deformation zone, Basin Res., 3, 39-48, 1991.

Sakellariou, D. and Tsampouraki-Kraounaki, K.: Offshore faulting in the Aegean Sea: A synthesis based on bathymetric and seismic profiling data, Bulletin of the Geological Society of Greece, 50, 124-133, 2016.

Sakellariou, D. and Tsampouraki-Kraounaki, K.: Plio-Quaternary Extension and Strike-Slip Tectonics in the Aegean, in: Transform Plate Boundaries and Fracture Zones, edited by: Duarte, J., chap. 14, Elsevier, 2018.

Sakellariou, D., Rousakis, G., Vougioukalakis, G., Ioakim, C., Panagiotopoulos, I., Morfis, I., Zimianitis, E., Athanasoulis, K., Tsampouraki-Kraounaki, K., Mpardis, D., and Karageorgis, A.: Deformation pattern in the western North Aegean trough: preliminary results, Bulletin of the Geological Society of Greece, 50, 134-143, 2016.

Sakellariou, D., Rousakis, G., Morfis, I., Panagiotopoulos, I., Ioakim, C., Trikalinou, G., Tsampouraki-Kraounaki, K., Kranis, H., and Karageorgis, A.: Deformation and kinematics at the termination of the North Anatolian Fault: the North Aegean Trough horsetail structure, INQUA Focus Group Earthquake Geology and Seismic Hazards, available at: http://paleoseismicity.org (last access: 14 January 2019), 2018.

Savage, S. B. and Hutter, K.: The motion of a finite mass of granular material down a rough incline, J. Fluid Mech., 199, 177-215, 1989.

Sequeiros, O. E., Naruse, H., Endo, N., Garcia, M. H., and Parker, G.: Experimental study on self-accelerating turbidity currents, J. Geophys. Res.-Oceans, 114, https://doi.org/10.1029/2008JC005149, 2009.

Shepard, D.: A two-dimensional interpolation function for irregularly-spaced data, in: Proceedings of the 1968 23rd ACM national conference, 517-524, ACM, 1968.
Strozyk, F., Strasser, M., Förster, A., Kopf, A., and Huhn, K.: Slope failure repetition in active margin environments: constraints from submarine landslides in the Hellenic fore arc, eastern Mediterranean, J. Geophys. Res.-Sol. Ea., 115, https://doi.org/10.1029/2009JB006841, 2010.

Suc, J.-P., Popescu, S.-M., Do Couto, D., Clauzon, G., Rubino, J.L., Melinte-Dobrinescu, M. C., Quillévéré, F., Brun, J.-P., Dumurdžanov, N., Zagorchev, I., Lesiæ, V., Tomiæ, D., Meyer, B., Macalet, R., and Rifelj, H.: Marine gateway vs. fluvial stream within the Balkans from 6 to $5 \mathrm{Ma}$, Mar. Petrol. Geol., 66, 231245, 2015.

Synolakis, C. E.: The runup of solitary waves, J. Fluid Mech., 185, 523-545, 1987.

Tappin, D.: Submarine mass failures as tsunami sources: their climate control, Philos. Trans. R. Soc. A, 368, 2417-2434, 2010.

Tappin, D., Watts, P., McMurtry, G., Lafoy, Y., and Matsumoto, T.: The Sissano, Papua New Guinea tsunami of July 1998 - offshore evidence on the source mechanism, Mar. Geol., 175, 1-23, 2001.

Tappin, D. R., Watts, P., and Grilli, S. T.: The Papua New Guinea tsunami of 17 July 1998: anatomy of a catastrophic event, Nat. Hazards Earth Syst. Sci., 8, 243-266, https://doi.org/10.5194/nhess-8-243-2008, 2008.

Ten Brink, U., Barkan, R., Andrews, B. D., and Chaytor, J.: Size distributions and failure initiation of submarine and subaerial landslides, Earth Planet. Sc. Lett., 287, 31-42, 2009.

Ten Brink, U. S., Geist, E. L., and Andrews, B. D.: Size distribution of submarine landslides and its implication to tsunami hazard in Puerto Rico, Geophys. Res. Lett., 33, https://doi.org/10.1029/2006GL026125, 2006.

ten Brink, U. S., Chaytor, J. D., Geist, E. L., Brothers, D. S., and Andrews, B. D.: Assessment of tsunami hazard to the US Atlantic margin, Mar. Geol., 353, 31-54, 2014.

Trifunac, M. and Todorovska, M.: A note on differences in tsunami source parameters for submarine slides and earthquakes, Soil Dyn. Earthq. Eng., 22, 143-155, 2002.

Twichell, D. C., Chaytor, J. D., Uri, S., and Buczkowski, B.: Morphology of late Quaternary submarine landslides along the US Atlantic continental margin, Mar. Geol., 264, 4-15, 2009.

Urgeles, R. and Camerlenghi, A.: Submarine landslides of the Mediterranean Sea: Trigger mechanisms, dynamics, and frequency-magnitude distribution, J. Geophys. Res.-Earth, 118, 2600-2618, 2013.

Urlaub, M., Talling, P. J., Zervos, A., and Masson, D.: What causes large submarine landslides on low gradient $\left(<2^{\circ}\right)$ continental slopes with slow ( $\sim 0.15 \mathrm{~m} / \mathrm{kyr})$ sediment accumulation?, J. Geophys. Res.-Sol. Ea., 120, 6722-6739, 2015.

Völker, D., Scholz, F., and Geersen, J.: Analysis of submarine landsliding in the rupture area of the 27 February 2010 Maule earthquake, Central Chile, Mar. Geol., 288, 79-89, 2011.

Ward, S. N.: Landslide tsunami, J. Geophys. Res.-Sol. Ea., 106, 11201-11215, 2001.

Yalçıner, A. C., Alpar, B., Altınok, Y., Özbay, İ., and Imamura, F.: Tsunamis in the Sea of Marmara: Historical documents for the past, models for the future, Mar. Geol., 190, 445-463, 2002. 